\title{
Morphological, Biochemical and Physiological Basis of Yield Variation among Promising Rice (Oryza sativa L.) Genotypes
}

\author{
Prashant B. Kardile*, Milind R. Nimje, Murad M. Burondkar and Sanjay G. Bhave \\ Department of Agricultural Botany, College of Agriculture, Dapoli, Dr. Balasaheb Sawant \\ Konkan Krishi Vidyapeeth, Dapoli-415712, India
}

*Corresponding author

\section{A B S T R A C T}

Keywords

Rice, Photosynthesis, Stomatal conductance, Chlorophyll

Article Info

Accepted:

26 March 2018

Available Online:

10 April 2018
A field experiment was conducted with 6 pre-release cultures, 5 pre-release rice hybrids and 2 checks genotypes to study the yield variation during kharif. RTN-49-2-3-1-2 took minimum time for flowering and maturity. Maximum grain yield (31.76 g/plant) was recorded in RTNRH-10 followed by RTNRH-17 (30.40 g/plant). Photosynthesis rate and stomatal conductance was found significantly higher in RTN-13-4-2-3-1 (23.446 $\left.\mu \mathrm{mol} \quad \mathrm{CO}_{2} \quad \mathrm{~m}^{-2} \mathrm{sec}^{-1}\right)$ and RTNRH-10 (0.0603 $\left.\mu \mathrm{mol} \quad \mathrm{H}_{2} \mathrm{O} \quad \mathrm{m}^{-2} \mathrm{sec}^{-1}\right)$ respectively. Total chlorophyll content was higher in RTNRH-10 (1.5723 $\mathrm{mg} / \mathrm{g}$ ). RTNRH-10 recorded maximum grain yield as compared to other genotypes.

\section{Introduction}

Rice is one of the most important food grain crops of the world. Rice is the staple food of most of the peoples in Asia. The problem for variation in yield in terms of growth and development of crop plant is obviously very complex as it ultimately involves the interactions of external factors with the physiological processes of plant. For understanding the causes for variation in grain yield as well as attempts forward increasing grain yield, a physiological approach is basic such an approach and understanding is useful for proper crop management to maximize the yield and also evolving high yield plant types.
Grain yield in rice is a complex character which is influenced by several physiological factors and hence the selection made for one character generally brings about a simultaneous change in others. The present investigation was undertaken to study the physiological basis of yield variation among promising rice.

\section{Materials and Methods}

A field experiment was conducted during kharif at research farm of Department of Agril. Botany, College of Agriculture, Dapoli. Dist- Ratnagiri, Maharashtra State on lateritic soil with 6 pre-release cultures, 5 pre-release 
hybrids and 2 checks. The experiment was laid following randomized block design with three replications. The plot size was $2 \times 2.25 \mathrm{~m}$ and each genotype with ten rows and fifteen plants in each row. Recommended dose of nitrogen, phosphorous, potassium i.e. 100, 50, and 50 $\mathrm{kg} /$ ha respectively were applied. Recommended package of practices were followed. The photosynthesis rate and stomatal conductance was measured by infrared gas analyzer (LICOR- 6400). The total chlorophyll content of the leaves was calculated by Arnon (1969). The yield and yield components were recorded at harvest. The data was analyzed statistically.

\section{Results and Discussion}

\section{Growth parameters}

Experimental results revealed that all the genotypes perform in terms of vegetative growth (Table-1). Highest plant height $(98.87 \mathrm{~cm})$ was recorded in KJTRH-21 followed by RTNRH-17, RTNRH-10, RTNRH-18, RTN-49-1-1-2 and RTN-1-1-2-1. Ligen (1994) also observed hybrids with taller canopy and grain yield. Highest total number of tillers per plants was recorded in RTNRH17(15.27) followed by genotypes RTNRH-10 and RTNRH-18. The variability for tiller number in rice has been reported by Golam (2001). Genotypes RTN 49-2-3-1-2, RTN-1-12-1, RTN-99-1-2 and KJTRH-21 took minimum time for flowering and maturity. However, RTNRH-10, RTNRH-14 and RTNRH-17 took longer duration for flowering and maturity. The variation in days to flowering and maturity was also reported by Srinivasulu et al., (1999).

\section{Yield and yield attributes}

Perusal of the data (Table 1) revealed that number of panicles per plant was maximum in RTNRH-10 (13.30) recorded significantly highest number of panicle per plant than rest of the genotypes expect RTNRH-17. Similar results were in accordance with Surekha et al., (1999) and Golam (2001). The number of spikelets per panicles was highest in RTN-491-1-2 and RTNRH-10. Such a variation in respect of number of spikelets per panicle was also reported by Subramanian et al., (1998). 1000 grain weight was maximum in RTNRH 17 and RTNRH-10. The varietal difference for 1000 grain weight in rice have also been reported by Vange et al., (1999), Chandrashekhar et al., (2001) and Rajendran et al., (2002). RTNRH-10 (31.76g/plant) recorded highest grain yield per plant followed by RTNRH- 17 (30.40g /plant) as compared to other genotypes. Variation in grain yield in rice has been also reported by Hari et al., (1997), Golam (2001) and Ramarao (2004).

\section{Physiological parameters}

RTNRH-10 $\left(18.557 \mu \mathrm{mol} \mathrm{CO}_{2} \mathrm{~m}^{-2} \mathrm{sec}^{-1}\right)$ and RTN-13-4-2-3-1(23.446 $\left.\mu \mathrm{mol} \mathrm{CO} \mathrm{m}^{-2} \mathrm{sec}^{-1}\right)$ recorded significantly highest rate of photosynthesis at 60 DAS and 90 DAS respectively. The varietal difference for photosynthesis rate was also reported by Sharma et al., (1997), Pramodkumar (2000) and Pramodkumar (2002). RTN-13-4-2-3-1 $\left(0.0497 \mu \mathrm{mol} \mathrm{H} \mathrm{O} \mathrm{m}^{-2} \mathrm{sec}^{-1}\right)$ and RTNRH-10 $\left(0.0603 \mu \mathrm{mol} \quad \mathrm{H}_{2} \mathrm{O} \quad \mathrm{m}^{-2} \mathrm{sec}^{-1}\right)$ recorded significantly highest stomatal conductance at 60 and 90 DAS respectively.

The varietal variation for stomatal conductance was also reported by Pramodkumar et al., (2000) and Selvi et al., (2001). At 60 DAS, RTN-13-4-2-3-1 (2.0662 $\mathrm{mg} / \mathrm{g})$ recorded highest total chlorophyll content followed by KJTRH-21. At 90 DAS, RTNRH-10 (1.572 mg/g) recorded maximum total chlorophyll content followed by RTN-84-2-1-2. The varietal difference was also reported by Prasmodkumar (2002), Chauhan et al., (2003) and Ghosh et al., (2003). 
Table.1 Growth, yield and yield attributes of promising rice genotypes

\begin{tabular}{|c|c|c|c|c|c|c|c|c|}
\hline Genotypes & $\begin{array}{l}\text { Plant } \\
\text { height } \\
\text { (cm/plant) }\end{array}$ & $\begin{array}{l}\text { No. of } \\
\text { tillers } \\
\text { /plant }\end{array}$ & $\begin{array}{l}\text { Days to } \\
50 \% \\
\text { flowering }\end{array}$ & $\begin{array}{l}\text { Days to } \\
\text { maturity }\end{array}$ & $\begin{array}{l}\text { No. of } \\
\text { panicles } \\
\text { /plant }\end{array}$ & $\begin{array}{l}\text { No. of } \\
\text { spikelets / } \\
\text { panicle }\end{array}$ & $\begin{array}{l}1000 \\
\text { grain } \\
\text { weight }\end{array}$ & $\begin{array}{l}\text { Grain } \\
\text { yield per } \\
\text { plant } \\
\text { (g/plant) }\end{array}$ \\
\hline RTN-49-1-1-2-2-1 & 93.48 & 10.77 & 96.39 & 125.53 & 8.47 & 173.27 & 24.14 & 24.20 \\
\hline RTN-8-4-2-1-2 & 87.52 & 12.47 & 98.35 & 130.93 & 9.60 & 152.87 & 23.23 & 26.30 \\
\hline RTN-49-2-3-1-2 & 90.29 & 12.40 & 85.71 & 116.43 & 8.60 & 152.22 & 21.55 & 22.74 \\
\hline RTN-99-1-2 & 83.93 & 11.47 & 88.50 & 118.27 & 7.70 & 148.07 & 15.25 & 15.49 \\
\hline RTN-1-1-2-1 & 93.35 & 12.40 & 87.59 & 117.37 & 6.53 & 134.47 & 22.69 & 20.72 \\
\hline RTN-13-4-2-3-1 & 85.52 & 12.60 & 100.74 & 130.80 & 9.93 & 174.93 & 26.33 & 27.37 \\
\hline KJTRH-21 & 98.87 & 11.27 & 87.60 & 118.40 & 11.40 & 148.73 & 24.64 & 27.28 \\
\hline RTNRH-18 & 93.51 & 13.33 & 99.10 & 144.87 & 10.47 & 174.93 & 23.75 & 28.36 \\
\hline RTNRH-14 & 86.81 & 11.20 & 110.70 & 141.40 & 9.67 & 159.53 & 19.54 & 27.37 \\
\hline RTNRH-17 & 94.22 & 15.27 & 105.73 & 143.20 & 12.80 & 149.33 & 27.24 & 30.40 \\
\hline RTNRH-10 & 94.13 & 14.07 & 111.00 & 141.33 & 13.30 & 167.53 & 25.42 & 31.76 \\
\hline Jaya & 78.41 & 11.40 & 102.73 & 132.60 & 6.33 & 131.60 & 22.07 & 16.00 \\
\hline Sahyadri-3 & 86.40 & 12.07 & 98.53 & 127.70 & 7.73 & 106.53 & 20.27 & 14.74 \\
\hline SEm \pm & 2.53 & 0.80 & 0.79 & 0.86 & 0.65 & 4.72 & 0.96 & 0.97 \\
\hline CD (5\%) & 7.39 & 2.35 & 2.31 & 2.52 & 1.90 & 13.80 & 2.80 & 2.84 \\
\hline
\end{tabular}

Table.2 Physiological parameters of promising rice genotypes

\begin{tabular}{|c|c|c|c|c|c|c|}
\hline \multirow[t]{2}{*}{ Genotypes } & \multicolumn{2}{|c|}{$\begin{array}{l}\text { Photosynthesis rate } \\
\left(\mu \mathrm{mol} \mathrm{CO} \mathrm{Cm}^{-2} \mathrm{sec}^{-1}\right)\end{array}$} & \multicolumn{2}{|c|}{ 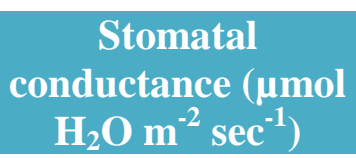 } & \multicolumn{2}{|c|}{$\begin{array}{l}\text { Total Chlorophyll } \\
\text { content (mg/g) }\end{array}$} \\
\hline & $\begin{array}{l}\text { At } 60 \\
\text { DAS }\end{array}$ & $\begin{array}{l}\text { At } 90 \\
\text { DAS }\end{array}$ & $\begin{array}{l}\text { At } 60 \\
\text { DAS }\end{array}$ & $\begin{array}{l}\text { At } 90 \\
\text { DAS }\end{array}$ & $\begin{array}{l}\text { At } 60 \\
\text { DAS }\end{array}$ & $\begin{array}{l}\text { At } 90 \\
\text { DAS }\end{array}$ \\
\hline RTN-49-1-1-2-2-1 & 11.363 & 20.989 & 0.0271 & 0.0509 & 1.831 & 1.223 \\
\hline RTN-8-4-2-1-2 & 10.606 & 17.461 & 0.0377 & 0.0538 & 1.890 & 1.396 \\
\hline RTN-49-2-3-1-2 & 3.032 & 12.820 & 0.0224 & 0.0342 & 1.377 & 0.858 \\
\hline RTN-99-1-2 & 1.138 & 10.296 & 0.0203 & 0.0568 & 1.885 & 0.523 \\
\hline RTN-1-1-2-1 & 7.169 & 20.197 & 0.0054 & 0.0323 & 1.533 & 0.885 \\
\hline RTN-13-4-2-3-1 & 16.886 & 23.446 & 0.0497 & 0.0567 & 2.066 & 0.987 \\
\hline KJTRH-21 & 14.792 & 19.991 & 0.0233 & 0.0401 & 1.975 & 1.133 \\
\hline RTNRH-18 & 9.463 & 22.054 & 0.0241 & 0.0456 & 1.346 & 0.988 \\
\hline RTNRH-14 & 12.357 & 19.610 & 0.0348 & 0.0456 & 1.322 & 1.122 \\
\hline RTNRH-17 & 13.826 & 23.139 & 0.0134 & 0.0333 & 1.544 & 1.285 \\
\hline RTNRH-10 & 18.557 & 22.414 & 0.0475 & 0.0603 & 1.440 & 1.572 \\
\hline Jaya & 8.424 & 19.715 & 0.0166 & 0.0332 & 1.152 & 0.984 \\
\hline Sahyadri-3 & 3.943 & 8.275 & 0.0167 & 0.0274 & 1.085 & 0.874 \\
\hline $\mathrm{SEm} \pm$ & 0.517 & 0.590 & 0.0164 & 0.0024 & 0.052 & 0.062 \\
\hline CD (5\%) & 1.509 & 1.723 & 0.0048 & 0.0071 & 0.152 & 0.181 \\
\hline
\end{tabular}


Present investigation results indicate RTNRH10 was superior to other promising rice genotypes in all aspects viz. growth characters, physiological parameters, yield and yield components.

\section{References}

Chandrasekhar, J., G. Rama Rao, B. Ravindranatha Reddy and K. B. Reddy (2001). Physiological analysis of growth and productivity of rice (Oryza sativa L.). Indian J. Plant Physiol., 6(2): 142-146.

Chauhan, J. S., C.V. Singh and R. K. Singh (2000). Inter-relationship of physiological growth parameters in rainfed upland rice. Oryza. 37(3): 234-235.

Ghosh, Mrityunjay; A.K. Pal, S.K. Pal and D.K. Dey (2003). Relationship of leaf area and chlorophyll content with yield of aromatic rice. Indian J. Plant Physiol., 8(2): 199200.

Golam, D.S. (2001). Studies on physiological basis for yield of hybrid rice (Oryza sativa L.). M.Sc. (Agri.) Thesis, Department of Agril. Botany, Konkan Krishi Vidyapeeth, Dapoli: 35-79.

Hari Om; S.K. Katyal and S.D. Dhiman (1997). Effect of time of transplanting and rice (Oryza sativa L.) hybrids on growth and yield. Indian J. Plant Physiol. 42(2):2161-264.

Ligen Jiang (1994). Main morphological characters of rice and their influence on grain yield. Oryza, 31: 260-263.

Pramodkumar (2002). Photosynthetic and yield performance of rice (Oryza sativa L.) genotypes under low temperature condition in hills. Indian J. Agric. Sci. 72(7): 383-388.

Pramodkumar; N. Jyothi Lakshmi, S.D. Dube and V.P. Mani (2000). Genotypic differences in photosynthesis and its associated parameters in relation to yields among barnyard millet genotypes under rainfed condition in hills. Indian J. Agric. Sci., 70(6): 374 -377.

Rajendran, K., A.S. Venkatakrishnan, M. Ramaswamy, M. L. Manoharan and S. Ramanathan (2002). Performance of rice hybrids in western zone of Tamil Nadu. Crop Res. 24(2): 273-275.

Raju, C.H. S., M.V. B. Rao and A. Sudarshanam (2003). Association in physiological growth parameters of rice hybrids. Madras Agri. J., 90(10-12): 621624.

Ramarao G. (2004). Dry matter production and nutrient uptake in rice. Madras. Agric. J., 91(4-6): 281-286.

Selvi, B; P. Rangaswamy and N. Nagarajan (2001). Combining ability analysis for physiological traits in rice. Oryza. 38 (1 and 2): 13-16.

Srinivasulu, K., R. Veeraraghavaiah and K. Madhavi (1999). Growth performance of rice hybrids under different method and densities of planting. Crop Res., 18: 17.

Subramanian, Bala V., M. Ilyas Ahmed and C. H. M. Vijaykumar (1998). Dry matter partitioning and leaf senescence after flowering in CMS and maintainer lines of rice. Indian J. Plant Physiol., 3(1): 1-4.

Surekha, K., M. Narayana Reddy and R. Mahender Kumar (1999). Yield attributes and yields of rice (Oryza sativa) hybrids as influenced by nitrogen sources and its split application. Indian J. Agron. 44(1): 80-88.

Vange, T., A.A. Ojo and L.L. Bello (1999). Genetic variability, stability and correlation studies in lowland rice (Oryza sativa) genotypes. Indian J. Agric. Sci., 69(1): 30-33.

\section{How to cite this article:}

Prashant B. Kardile, Milind R. Nimje, Murad M. Burondkar and Sanjay G. Bhave. 2018. Morphological, Biochemical and Physiological Basis of Yield Variation among Promising Rice (Oryza sativa L.) Genotypes. Int.J.Curr.Microbiol.App.Sci. 7(04): 3130-3133. doi: https://doi.org/10.20546/ijcmas.2018.704.355 